\title{
PFKM wt Allele
}

National Cancer Institute

\section{Source}

National Cancer Institute. PFKM wt Allele. NCI Thesaurus. Code C104790.

Human PFKM wild-type allele is located in the vicinity of $12 q 13.11$ and is approximately 41 $\mathrm{kb}$ in length. This allele, which encodes 6-phosphofructokinase, muscle type protein, plays a role in muscle cell metabolism of glucose. Mutation of the gene is associated with glycogen storage disease type 7. 